\title{
Dokumentation
}

\section{THE DEVELOPMENT OF THE LAW OF THE SEA IN BRAZIL AND ITS PERSPECTIVES}

\author{
Vitoria dos SANTOS Costa
}

The Law of the Sea in Brazil developed greatly since the initial period of the Independence until 1970, especially in relation to the delimitation of the Territorial Sea, from the notion of the cannon shot rules, of the three miles, which lasted for a long time, to the six miles, the twelve miles, and, finally, to the present 200 miles, of which Brazil has proven to the international community to be one of its most demanding advocates.

The Law of the Sea is, obviously, vast, "La Merdes Juristes", to cite Lapradelle, which does not correspond to the natural formation of the maritime milieu. As René-Jean Dupuy affirmes, "à l'unicité écologique du milieu marin, trés tôt, les hommes ont répondu par une hétérogénéité du droit applicable"' 1 . The maritime space can only be studied and presented globally and not in tight compartments. Beginning on the water surface one goes to the maritime depths, passing through the Continental Shelf and through the mineral and living resources of the same space, with their respective fishing and exploration. We are trying, here, to give a synthetic and objective view of what we could call the Law of the Sea in Bra$\mathrm{zil}^{2}$, encompassing the laws and opinions about the Territorial Sea, the Continental Shelf and fishing, as well as the perspectives being announced.

\section{The Cannon Shot}

During centuries, Brazil was a Portuguese colony and as such all the political, legislative and administrative criteria of Portugal were imposed on it.

In 1822, Independence was declared and Brazil was born as an Independent State, with all the problems inherent to its new condition and the functions of own legislator in the most diverse branches of Law, including, the Law of the Sea. The first administrative Act, dealing with this matter, was on July 31, 1850, through Circular No. 92, dispatched by the Ministry of War to the Presidents of the Maritime Provinces, determining, as demarcation of the Territorial Sea, the distance of a cannon shot. At the time, the legislation followed the same criterion of the "Cannon Shot" of Alvará of May 4th, 1805, which served as law of the Royal government of Portugal, in which the width of the Portuguese territorial waters was defined $^{3}$.

"Depuis leur accession à l'indépendance, les Etats riverains en voie de développement ont pris conscience non seulement de leur paüreté, mais également de l'immense potentiel des ressources marines adjacentes. Cette double constatation devait être rapidement synthétisée

1 See DUPUY, René-Jean, Les implications du Droit Positif de la Mer sur le Développement du Bassin Mediterranéen consideré comme une Unité Ecologique, Université de Nice, I. D. P. D., p. 1.

2 The Brazilian coast constitutes a long front whose perimeter is $5.864 \mathrm{~km}$. However, taking into account the convolutions of that coast, it is thought that it reaches bigger dimensions, approximately, $9.200 \mathrm{~km}$ in length, in LAFER, Celso, Brasil - Direito do Mar (LAW OF THE SEA), São Paulo, Dec. 1970, p. 1.

3 See BRANDAO, Eduardo H. Serra, Aguas Jurisdicionais Portuguesas (Portuguese Jurisdictional Waters), Junta d e Investigações do Ultramar, Centro de Estudos Políticos e Sociais, Estudos de Ciências Políticas e Sociais, No. 86, Lisboa, 1971, p. 11. Vale acrescentar: "Não existe no Direito Português norma onde de forma clara se defina a largura do mar territorial para todos os ef eitos. O próprio Alvará de 1805 referia-se de forma vaga a distância que 'abranger o tiro canhão" ", p. 27 (It is worth to mention: "There is no norm in the Portuguese Law where the width of the territorial sea is clearly defined, for all effects, The Alvará of 1805 itself referred in a very vague manner to the distance that: 'a cannon shot would reach'", p. 27). 
dans ce que certains auteurs qualifient de 'bioma' ou 'ecosystem theories"'4: "il y a un lien indissoluble entre la terre, l'homme et la mer, entre le développement économique et les vastes ressources de l'océan"5. La mer et l'homme constituent une unité biologique, la population de l'Etat riverain ne constitue qu'un "maillon" de cette chaîne biologique s'étendant des végétaux microscopiques aux grands mammifères marins"6.

\section{The Three Miles}

The width of three miles, established with the intention of neutrality, was adopted through Circular No. 43, of August 25th 1914, of the Ministry of Foreign Relations, directed towards the state governments and the Ministries of War and of the Navy. The First World War plowed through Europe.

The width of three miles was repeated in several acts later on: the Decree 16.183 of October 25th, 1923, which approved and had carried out the Regulations of the Directory of Fishing and Sanitation of the Coast, which referred to the distance of three miles beginning "with the straight lines that unite the most prominent points in the coast, not farther than 10 miles one from the other, towards the high seas" (only paragraph of article 20); the Regulations for the Capitainship of Ports; Decree No. 24.288 of May 24th, 1935; Decree 220-A of July 3, 1935, and Decree No. 5.798 of June 11 th, 1940. This last one, the Regulations for Maritime Traffic, said in its first paragraph of art. 17: "In the places where the coast, including the islands coasts, curves forming bays, inlets, etc., the three miles of Territorial Sea will be counted beginning on the line which will unite obliquely the two opposite points nearer the inflection of the coast and which are approximately 12 miles from each other"7.

\section{The Hague Conference}

At the same time that Brazilian Legislation was concerned with the limit of the Territorial Sea and consolidated the measurement of three miles, in the International Community, was being carried out by initiative of the League of Nations, the Conference for the Codification of International Law, and whose working agenda was the problem of the Law of the Sea. It was the Hague Conference, which took place in 1930 and in which Brazil participed.

The Hague conference was held from March 13 to April 12, 1930 with 47 States represented ${ }^{8}$. One of its main goals was the definition of the width of the Territorial Sea. This Conference took place through the most difficult controversies. The big maritime potencies, such as Great Britain, the United States, Japan, etc., united themselves around the three miles rule; some others, like France and Germany, admitted the same distance plus an adjacent zone; Finland and Iceland wanted a width of four miles plus an adjacent zone; six miles, plus an adjacent zone for Cuba, Spain, Iran, Turkey, etc. Other countries debated for intermediary

\footnotetext{
4 See Cisneros: "The 200 miles limit in the South Pacific: a new position in international law with a human and juridical content". ABA Section of International Law and Comparative Law, 1964. Proceedings 56 (1965), p. 58-60.

5 Declaration of Mr. Zegers (Chile) to the 48 session Seabed Committee, Doc. ONU A/AC. 138/SR. 48, p. 40.

6 See DUPUY, René-Jean et PIQUEMAL, Alain, Les appropriations nationales des Espaces Maritimes, I. D. P. D., 1972, pp. 44-45.

7 See RANGEL, Vicente Marotta, Natureza Jurídica e Delimitação do Mar Territorial, (Jurisdictional Nature and Demarcation of the Territorial Sea), 2a. Edição, Ed. Rev. dos Tribunais, 1970, S. Paulo, pp. 137-138.

8 See League of Nations Conference for the Codification of International Law, vol. II: Territorial Waters. League of Nations, Doc. C. 74 M 39, 1929. S. League of Nations, Acts of the Conference for the Codification of International Law weld at the Hague from March 13 to April 12, 1930, vol. III: Territorial Waters, Minute of the Second Committee. League of Nations, Doc. C. 351 (6) M, 145 (6) 1930 , V.
} 
solutions; Chile, for example, six miles without the adjacent zone, Portugal, twelve miles or six miles with adjacent zones.

The first article of the Convention defined thus the Territorial Sea:

- "The territory of the State includes a part of the sea designated in this Convention as Territorial Sea.

The sovereignty over this zone will be executed in the conditions established by the Convention and by other rules of International Law"9.

Speaking of Brazil's position, it is apropos to remind that the eminent Brazilian jurisconsult Epitácio Pessoa proclaimed the width of six miles for the Territorial Sea, in his Project of the Code of International Public Law, presented in 1910. But it is more interesting to cite the text of the Project itself. Thus, in the chapter about the Law of the Sea, we can read particularly that:

"The sovereignty of the State extends to his own territory, to the Territorial Sea, to the corresponding air space and to the persons and things within these limits . .." (article 27), and that "The Territorial Sea constitute the waters that touch the coast of the State up to a distance of six maritime miles (11 m, 112), beginning at the low-tide line" (Article 53) ${ }^{10}$. The Project of the Code does not deal anywhere with the Continental Shelf, at that time a notion still undefined and without the economic importance it had later on. Epitácio Pessoa's Project contained 721 articles ${ }^{11}$.

\section{The Failures of the Hague Conference}

Despite its failure in the difficult task of obtaining an international agreement on the width of the Territorial Sea, the Hague Conference, undoubtedly, reached some important accomplishments, among which it is convenient to mention two of a positive nature and one of a negative character. The two positive ones consisted in: elaborating the articles, a result of the work of the subcommittees of the Second Commission, which would prove very valuable, later on, for the preparatory work accomplished by the United Nations Commission on International Law having in mind the First Conference in Geneva, and putting an end to the confusion which existed during centuries concerning the juridical status of the water zones adjacent to the coast, thus becoming clearly defined in the Hague the two notions of "Territorial Sea", over which the riverine States has sovereignty, i. e., rights essentially equal to those which it has over its territory, and "adjacent zone", over which the State can only claim the exercise of certain specialized jurisdictions.

The Conference had a third result, which in spite of its negative character, as it was pointed out, was, maybe, of greatest transcendence: it ended for good with the erroneous thesis "so spread out however so rarely delved into" that the so called "rule of the three miles" constituted a norm of international law. To this respect, the provisional opinions "expressed in the 13th session of the Second Commission on April 3, 1930, were very significant"12.

In the Hague, Brazil voted against the institution of an adjacent zone, no matter its extension. And in spite of having defended the extension of the Territorial Sea to six miles, how-

9 See GIDEL, Gilbert, La Mer Territoriale et la Zone Contigue, R. C. A. D. I., 1934, II, Vol. 48. p, 795.

10 Article 54 in its only paragraph and articles 55 and 56 deal with the problem of gulfs, bays and estuaries.

11 See PESSOA, Epitacio, his Projeto de Codigo de Direito Internacional Público (Project of the Code of International Public Law), of november 12, 1910, p. 69, 72-74, in PANDECTAS BRASILEIRAS, ESPINOLA, Eduardo, Vol. 20, 1 and 2 parts, Rio de Janeiro, Imprensa Nacional, 1927, 600 p.

12 See OEA/Ser. Q. II. 4, CJI-7 - Volume I - Derecho del Mar (Law of the Sea) december 1971, p. 91. 
ever, the Brazilian legislation continued to adopt the system of three miles. In a study concerning that subject, Minister Carlos Calero Rodriguez refers to the fact as a "result of certain legislative inertia" given that position in the Hague and later on in Geneva ${ }^{\mathbf{1 3}}$.

\section{Brazilian Continental Shelf}

On November 8, 1950, through Decree No. 28.840, Brazil declared the Continental Shelf, integrated to its national territory. Its first considering of a general character, determines, - "that the submarine shelf, which borders the continents and islands and that extende to the high sea, is a true submersed territory and constitutes along with the adjacent lands, one single geographical unit"14.

The Third considering aims at circumstances, specifically Latin-American, even defining positions taken by some countries of the New Continent in relation to this subject:

- "that, as a result, several countries of America, through declarations, or Decrees of their Presidents, have asserted their rights of dominion or jurisdiction, or of sovereignty over the submarine shelf's part, adjacent and corresponding to the national territory (Declarations of the President of the United States of America, September 28, 1945; of the President of Mexico, October 29, 1945 and of the President of Chile, June 25, 1947; Decree of the President of Argentina, October 11, 1946, and of Peru, August 1, 1947)".

It can be noted, at the time, that Brazil, through Decree No. 28.840, adhered to the LatinAmerican reformulating movement of the Law of the Sea, initiated in 1947. This movement had a regionalist characteristic.

The provisions of Decree No. 28.840 were completed by those of Decree No. 62.837 of June 6, 1968, and of No. 63.146 of August 26, 1968, that establish the process for obtaining concessions and licences for the exploration of the Continental Shelf.

Later on, Decree-Law No. 1.098 of March 25, 1970, which extended the Territorial Sea to a width of 200 miles, in its 2nd article specifies that:

- "The sovereignty of Brazil extends itself to the air space above the Territorial Sea, as well as to the bed and underground of this sea" which can be translated as the Continental Shelf under the Territorial Sea.

On the other hand, the Constitution of the Federative Republic of Brazil of 1967, altered with amendments in 1969, includes among the possession of the Union: the Continental Shelf and the Territorial Sea (art. 4).

\section{The Geneva Conferences of 1958 and 1960}

The Geneva Conference of 1958 assembled a large amount of countries. The topics dealt with gave way to the elaboration of four conventions:

a) Territorial Sea and Adjacent Zone;

b) High Seas;

c) Fishing and Conservation of the Living or Biological Resources of the High Seas;

d) Continental Shelf and the Additional Jurisdiction on Controversies.

Brazil neither signed nor ratified any of the four Conventions.

13 See RODRIGUEZ, Carlos Calero, O Problema do Mar Territorial (The Problem of Territorial Sea), Rev. Bras. de Política Internacional, Rio de Janeiro, Ano XIII, mar./jun., 1970, no 49/50, p. 122.

14 See Decree no 28.840 . 
The Conference ended without an aswer to the fundamental question of the width of the Territorial Sea and thus, the United Nations summoned another Conference for 1960, which took place, but it also did not find a solution for the problem of the width of the Territorial Sea.

Ambassador Gilberto Amado, Chief of the Brazilian Delegation affirmed, at the end of the Conference, that "the only existing rule concerning the extension of the Territorial Sea is that there is no steady rule".

Regarding the Conference of 1960 , it ended without any objective result about the widely discussed question of the width of the waters.

\section{Brazil and the Six Miles}

The law about the three miles lasted for a long time in Brazil. It was Decree-Law No. 44 of November 18, 1966, which altered the limits of the Brazilian Territorial Sea and established an adjacent zone, besides the other complementary provisions. This Decree-Law is composed of only five articles:

Art. 10 says:

- "The Territorial Sea of the United States of Brazil includes all the waters that touch the country's coast, from cape Orange to the mouth of the Oiapoque river, to the rivulet Chuí in the State of Rio Grande do Sul, in a strip six maritime miles wide, beginning at the low tide line, adopted as reference in all Brazilian nautical maps".

Art. 20 refers to the Adjacent Zone:

- "An Adjacent Zone six maritime miles wide, measured beginning from the external limits of the Territorial Sea, is under the Jurisdiction of the United States of Brazil concerning the prevention and repression of the infringements of Brazilian law in terms of customs, fiscal, health and immigration police".

Article 30 establishes the norms over the exclusive rights of fishing, of the jurisdiction concerning fishing and the exploitation of the living resources of the sea, in its Territorial Sea" 15 .

\section{Brazil and the Twelve Miles}

The alterations of the limits of Brazilian Territorial Sea to twelve miles occured through Decree-Law No. 553 of April 25, 1969.

Article 10 specifies that:

- "The Territorial Sea of the United States of Brazil includes all the waters that touch the country's coast, from cape Orange to the mouth of the Oiapoque River to the rivulet Chuí in the State of Rio Grande do Sul, in a strip twelve maritime mile wide, beginning at the low tide line adopted as reference in all Brazilian nautical maps".

Because of the adoption of the twelve miles limit of Territorial Sea, Brazil abolished the Adjacent Fishing Zone, thus incorporated to the Territorial Sea.

However the validity of this Decree would be very short, since, less than twelve months later, Brazil adopted the 200 miles regime.

15 See Decree-Law no 44. 


\section{Miles of Territorial Sea in Brazil}

Brazil's Territorial Sea was settled in 200 miles through Decree-Law No. 1098 of March 25, 1970.

Moreover, the 70's were very fertile years for the international community through the Organization of the United Nations in the preparation of studies and efforts of re-formulation of the whole Law of the Sea, after the intervention of Ambassador of Malta, Arvid Pardo in the September 1967 session.

It is interesting to note the complete text of Decree-Law 1.098:

Decree-Law No. 1.098 of March 25, 1970. Alters the limits of the Territorial Sea of Brazil and makes other provisions.

The President of the Republic, using the attributes that are his through article 55, item I of the Constitution, and taking into consideration that:

the special interest of the coastal State in the maintenance of the productivity of the live resources of the maritime zones adjacent to its coast is recognized by International Law; that each State has competence to establish its Territorial Sea within reasonable limits, taking into consideration geographical and biological factors as well as the needs of its population and the security and defense,

\section{Decrees:}

Art. 1st - Brazil's Territorial Sea comprises a 200 nautical miles wide strip, measured beginning at the low-tide line of the Brazilian continental and insular coast adopted as reference in the Brazilian nautical maps.

Single paragraph. In places where the coastal line presents deep bays or saliences or where there is series of islands along the coast or in its vicinity, the method of straight lines will be adopted, uniting appropriate points, to trace a line from which the Territorial Sea will be measured.

Art. 2nd. - Brazil's sovereignty extends to the air space above the Territorial Sea as wellas to the sea's bed and underground.

Art. 3rd. - All ships of all nationalities have the right to pass innocently through Brazilian Territorial Sea.

$\$ 1$ - It is considered innocent passage the simple traffic through Territorial Sea, without any other activity not pertaining to navigation and without unnecessary stops.

$\$ 2$ - In the Territorial Sea all ships must obey the Brazilian rules destined to guarantee peace, order and security as well as to avoid water pollution and danger to the water resources.

$\$ 3$ - The Brazilian government will establish the rules that, for security reasons, will seem necessary to enforce through war ships and through other foreign State ships.

Art. 4th - The Brazilian government will regulate fishing, having in mind the rational utilization and conservation of the living resources of the Territorial Sea, as well as the activities of research and exploration.

$\$ 1$ - The regulations will establish zones in which fishing will be reserved exclusively to Brazilian vessels.

$\$ 2$-In the zones of Territorial Sea open to fishing by foreign vessels, the same will be able to exercise their activities only when duly registered and authorized, and through the obligation of respecting Brazilian regulations. 
$\$ 3$-Special regimes of fishing, research and exploration in Territorial Sea will be defined through international agreements, based on reciprocity.

Art. 5th - This Decree-Law will go into effect on the date of its publication, cancelling Decree-Law No. 553, of April 25, 1969, and other contrary dispositions.

Brasilia, March 25, 1970; 149th year of the Independence and 82nd year of the Republic.

Emilio G. Medici.

Alfredo Buzaid.

Adalberto de Barros Nunes.

Mario Gibson Barboza.

When establishing its Territorial Sea to 200 miles, Brazil joined its South Atlantic neighbors who had already extended their limits to the same length: Argentina, for example, adopted this measure through law No. 17.094 of December 29, 1966 (published in the Official Bulletin of January 1, 1967). Its first article says:

- "The sovereignty of the Argentinian nation extends to the waters adjacent to its territory up to a distance of 200 nautical miles measured from the line of the lowest tides, except in the Gulfs of San Matias, Nuevo, and San Jorge, where it will be measured from the line that unite the cables that form the entrances"'16.

Uruguay's decision was taken on December 3, 1969 (D. 604/969). Here, its first article: - "The sovereignty of the Republic of Uruguay extends, beyound its continental and insular territory and its interior waters, to a zone of Territorial Sea of 200 nautical miles, measured beginning at the base lines"17.

\section{Fishing in Brazil}

At this point, it is convenient to approach the conditions of fishing in Brazil. Initially, the activities in this sector were regulated through two Codes, by Decree No. 23.672 of January 2nd, 1934, and Decree-Law No. 794 of October 19th, 1938 which said that there would be an adjacent zone of twelve miles, beyound the three-mile Territorial Sea, in which the Government would have exclusive jurrisdiction in fishing matters ${ }^{\mathbf{1 8}}$.

The Delegate-Law No. 10 of October 11 th, 1962 created the Superintendencia do Desenvolvimento da Pesca - SUDEPE - as an autonomous federal organism, which takes care of fishing, having as headquarters the city of Rio de Janeiro and is related to the Ministry of Agriculture ${ }^{19}$.

SUDEPE has several functions, such as:

- to elaborate the national plan for the development of fishing (P. N. D. P.) and to promote its execution;

- to furnish technical and financial assistance to the fishing industries;

- to put into effect the Fishing Code and the legislation of the activities related to fishing;

- to carry out agreements or contracts, projects related to the development of fishing;

- to establish the prices of the fishing products.

Other later Decrees established, mainly, measures to encourage the development of fishing, protection and stimulus to the fishing activities.

\footnotetext{
16 See America Latina y la Extensión del Mar Territorial - Regimen Jurídico, (Latin America and the extension of the Territorial Sea Juridical Regime), Rep. of Ururguay, Presidency of the Republic, Secretaria, Montevideo, 1971, p. 86.

17 See America Latina, op. cit. p. 11.

18 See LAFER, Celso, op. cit., p. 2.

19 See COSTA, Vitória dos Santos, L e Droit de la Mer et le Dévelopement en Amérique Latine, thèse de Doctarat de 3 e Cycle, Copirex, Nice, 1974, p. 150.
} 
Decree-Law No. 1.098 of March 25th, 1970 which altered the limits of the Territorial Sea, extending them to 200 miles says:

Art. 4 - "The Brazilian government will regulate fishing, having in mind the rational utilization and the conservation of the living resources of the Territorial Sea, as well as the activities of research and exploration.

$\$ 1$ - The regulations will establish zones in which fishing will be reserved exclusively to Brazilian vessels.

$\$ 2$ - In the zones of Territorial Sea open to fishing by foreign vessels, the same will be able to exercise their activities only when duly registered and authorized, and through the obligation of respecting Brazilian regulations.

$\$ 3$ - Special regimes of fishing, research and exploration in Territorial Sea will be defined through international agreements, based on reciprocity"20.

On April 1 st, 1971, Decree No. 68.459, based on the Decree-Law mentioned above, regulated fishing, having in mind the rational utilization and conservation of the living resources of the Brazilian Territorial Sea.

Chapter I - Of Fishing Zone - instructs mainly that:

"Art. 1st. - The following fishing zones are established in the Brazilian Territorial Sea:

I - Inside of a 100 nautical miles, wide strip measured beginning at the low tide line of the continental and insular Brazilian coast adopted as reference in Brazilian nautical maps.

II - Beyond the zone established in the last item, up to a limit of 200 nautical miles.

$\$ 1$ - In the zone referred to in item I of this article, all fishing activities will be carried out by Brazilian fishing vessels.

$\$ 2$ - In the zone referred to in item II of this article, the fishing activities will be carried out by Brazilian and foreign vessels"21.

\section{The Delimitation of the Sea in the Defense of the American Continent}

The formula for the extension of the Territorial Sea to such unusual distances did not appear for the first time and in the Americas with the attitudes of those States. Already in 1939, in the first consultation meeting of the Ministers of Foreign Relations of the American Republics, in Panama, a Declaration of the countries of the New World, from the United States to Argentina, excluding Canada, was emitted in which they declared themselves for neutrality before the conflict which had been, up to then, clearly European, and delimitated a maritime security zone of 300 miles around the continent.

After the War, in 1947, the T. I. A. R. - Interamerican Treaty for Reciprocal Defensewas signed in Rio de Janeiro, which through Art. 4th established a bigger zone than the one established in Panama since it runs from the North to the South Pole, organizing a system of collective defense based on the spirit or interest of American security. It is the first regional treaty done according to art. 51 of the Charter of the United Nations ${ }^{22}$.

\footnotetext{
20 See Decree-Law no. 1098.

21 See Decree no 68.549.

22 Article 51 of the Charter of the United Nations says: "Nothing in the present Charter shall impair the inherent right of individual or collective self-defense if an armed attack occurs against a Member of the United Nations, until the Security Council has taken measures necessary to maintain international peace and security. Measures taken by Members in the exercise of this right of self-defense shall be immediately reported to the Security Council and shall not in any way affect the authority and responsibility of the Security Council under the present Charter to take at any time action as it deems necessary in order to maintain or restore international peace and security“.
} 
The Treaty of Tlatelolco or Treaty of Banishiment of Nuclear Arms in Latin America, of February 14, 1967, also delimits a zone in its Art. 4th No. 2, which goes from Mexico to Argentina.

\section{The Declarations of Economic Defense and Development of South America The Conventions of the South Pacific States}

Between the years of 1952 and 1955, the governments of Chile, Ecuador and Peru signed in Santiago, Lima and Quito, the documents know under the following names:

I - Declaration about the Maritime Zone (Santiago de Chile, August 18, 1952);

II - Organization of the Permanent Commission of the Conference about the exploration and conservation of the maritime resources of the South Pacific (Santiago, August 18, 1952); III - Joint Declaration concerning the fishing problems in the South Pacific (Santiago, August 19, 1952);

V - Convention about the sanction system (Lima, December 4, 1954);

IV - Complementary Convention to the Declaration of sovereignty over the 200 miles maritime zone (Lima, December 4, 1954);

VI - Convention about the measures of vigilance and control of the maritime Zones of the undersigned countries (Lima, December 4, 1954);

VII - Convention about the acquisition of license for the exploration of the resources of the South Pacific (Lima, December 4, 1954);

VIII - Convention about the Special Zone of the Maritime Frontier (Lima, December 4, 1954);

- IX - Regulation of licenses for the exploration of the resources of the South Pacific (Quito, December 16, 1955);

- X - Protocol of adhesion to the Declaration about the Maritime Zone of Santiago (Quito, December 6, 1955) ${ }^{23}$.

These Declarations were related to problems of an economic nature and of the development of its countries, when they affirmed, for example, that:

"The Governments have the obligation to assure their people the necessary conditions for subsistence, and to find the means for their economic development. As result, it is their duty to take care of the conservation and protection of their natural resources and to regulate their utilization in order to obtain the best profit for their respective countries"24.

We cannot forget to mention, here, the exhaustive and complete job carried out by the Juridical Committee of the Organization of American States, which throughout many years elaborated pieces of work, opinions and resolutions about the Law of the Sea, under the most diverse prisms and legitimately involving American rights and interests.

These agreements and measures represented, without any doubt, an effort of integration and cooperation among the South Pacific States, demonstrating a tendency to institutionalize the Law of the Sea, which could serve as model for the whole continent.

This sub-regionalistic movement would be developed later on in the 70's with a more regionalistic character at the meetings of Montevideo and Lima. Its repercussions and influences on the other countries of the continent were undeniable, as it was to be expected.

23 See America Latina, op. cit. p. 115 to 196. See COSTA, Vitoria dos Santos, op. cit. pp. 224-225.

24 See COSTA, Vitoria dos Santos, op. cit. pp. 314-315. 


\section{The Meeting at Montevideo in 1970}

By initiative of the Republic of Uruguay and by its convocation, a meeting in Montevideo was carried out from May 4 to May 8, 1970, to debate all the Law of the Sea and at the end of it a joint Declaration was emitted by the nine Latin American States which backed the 200 miles: Chile, Peru, Ecuador, Panama, El Salvador, Argentina, Brazil, Nicaragua and Uruguay. Its was the beginning of a regionalist position of the Law of the Sea by the LatinAmerican States. The meeting's programme was long and the following topics were discussed:

1 - "Consideration of the inquiry of the General Secretary of the United Nations about the convocation of an International Conference about the regimes of the Sea (Resolution 2574[A]XXIV General Assembly);

2 - Fixing of positions caused by the parallel answer of the States with a 200 mile maritime jurisdiction to the inquiry of the Soviet Union and the United States;

3 - Consideration of principles and common actions about the Law of the Sea;

4 - Besides this, the following topics presently being discussed in the United Nations could be treated:

a) Regime of the Marine and Oceanic seabed beyond the limits of the National Jurisdictions;

b) Denuclearization of oceanic seabed;

c) Definition of the Continental Shelf'25.

In the Montevideo Declaration the reference to the 200 miles for the Territorial Sea is not part of the text itself but of one of the initial considerations:

"In agreement with the said juridical principles, the undersigned States, because of their peculiar conditions, have extended their sovereignty or their rights exclusive of jurisdiction over the maritime adjacent zone to their coasts, their soil, and their subsoil to a distance of 200 nautical miles, measured beginning at the base line of the Territorial Sea".

It is interesting to mention that Brazil in the meeting of Montevideo, affirmed that: the Delegation of Brazil accepts paragraph 6 of the Declaration in such a way:

1 -The freedom of navigation mentioned there is the one admitted in the Territorial Sea, i. e., innocent passage, as it is defined in Brazilian legislation;

2 - In reference to overflying, it doesn't mean that the regime normally applied to the air space above the Territorial Sea should be derogated ${ }^{\mathbf{2 6}}$.

Resolution No. 3 of the Meeting of Montevideo foresaw the coming conclave about aspects of the law of the Sea, which really took place in Lima, Peru from August 4 to August 8, 1970.

\section{The Meeting of Lima}

Following the Meeting of Montevideo came the Meeting of Lima, in August of 1970, in which a greater number of Latin-American States participated: Argentina, Barbados, Bolivia, Brazil, Colombia, Chile, Ecuador, El Salvador, Guatemala, Honduras, Jamaica, Mexico, Nicaragua, Panama, Paraguay, Peru, Dominican Republic, Trinidad and Tobago, Uruguay and Venezuela. Eight countries sent observers: Canada, South Korea, Costa Rica, India, Island, United Arab Republic, Senegal and Yugoslavia, as well as the United Nations

\footnotetext{
25 See Documentos de la Reunión de Montévideo sobre el Derecho del Mar, (Documents of the Meeting of Montevideo about the Law of the Sea), Ministerio de Relaciones Exteriores, Rep. Oriental del Uruguay, Montevideo, MCMLXX, p. 35.

26 See Declarations of the delegations, op. cit. p. 12.
} 
and the Organization of American States. The Juridical Secretary and Sub-Secretary of the Permanent Commission of the South Pacific attended as special guest ${ }^{27}$.

The meeting's agenda included three topics:

1 - Basic principles about the Law of the Sea;

2 - Coordination of the positions of the Latin-American States about the problems related with the marine and oceanic seabed and their subsoils, beyond national jurisdiction; 3 - Coordination in front of other initiatives in progress related to the Law of the Sea. The Declaration signed by the participants did not mention the expression 200 miles in any considering or article. It deals mainly with the aspects of geographical, geological and biological realities.

\section{The Meeting of the Dominican Republic}

Finally, on June 9, 1972, at the Meeting in the Dominican Republic, another Declaration was signed which was called "Declaration of Principles" (Santo Domingo Declaration) ${ }^{\mathbf{2 8}}$ and which is divided in several parts:

a) Territorial Sea;

b) Patrimonial Sea;

c) Continental Shelf;

d) International marine floors;

e) High Sea;

f) The contamination of the Sea;

g) Regional Cooperation.

About the Territorial Sea it proclaims that the width of this zone and the manner in which it is delimited must be the object of an agreement of international range, but it admits that every State has the right to fix or establish their width of its Territorial Sea up to a limit of twelve nautical miles, measured beginning with the applicable base line. In this zone all ships from any State, even those that don't have a coast, have the right of innocent passage. The sovereignty of the State includes the adjacent waters known as Territorial Sea, the air space above the sea, its soil and subsoil.

About patrimonial sea (a new creation of the meeting) it also should be the object of an international agreement; its width, taken into account its geographical circumstances, should not exceed a distance of 200 miles included the Territorial Sea. The coastal State exercises its rights of sovereignty over the natural resources, renewable or not, found in the sea, the soil and subsoil of an adjacent zone to the Territorial Sea. The riverine State has the right to promote and regulate scientific research in the Territorial Sea, and also to adopt the necessary measures to avoid the pollution of the environment and assure the sovereignty over the resources. The delimitation of this zone will be done among two or more States in agreement with the pacific means foreseen in the Charter of the United Nations. In the Patrimonial Sea, the ships and aircrafts of all States, with er without coast, have the right of free navigation an flight to comply with the exercise of the rights of the riverine State over the sea and the freedom to extend or place submarine cables ${ }^{29}$.

27 See VARGAS, Jorge, Terminologia sobre Derecho del Mar, (Terminology about the Law of the Sea), CEESTEM, Mexico, 1979, p. 234.

28 The following countries participated in this meeting: Barbados, Colombia, Costa Rica, El Salvador, Guatemala, Guiana, Haiti, Jamaica, Mexico, Nicaragua, Panama, Dominican Republic, Trinidad and Tobago, and Venezuela. Observers were sent from Brazil, Argentina, Chile, Uruguay, Equador, Peru and certain international organizations such as U.N., O.A.S., and F.A.O. 


\section{Brazil is not Intransigent Any More Regarding the Territorial Sea Matter}

The Brazilian positions, regarding the width of the Territorial Sea, exposed in the above items, all originate from unilateral acts, which is explained not only by the difficulties in obtaining a consensus in any of the international meetings carried out up to now, under the initiative of the United Nations, but also by the undelayable necessity of the country of establishing lines of defense of its juridical, political, economical and social interests. In spite of the interest shown in maintaining those attitudes, especially thelast one, that is, the 200 miles Territorial Sea, nothing indicates that Brazil, attending all the meetings promoted by the United Nations, will refuse to debate new formulas capable of coordinating and involving the common interests of the States, in the collective benefit of humanity, and under the protection of International Public Law, whose main goal is the wide and harmonious relationship among nations.

In a long and important interview to the "Jornal do Brasil", Rio de Janeiro, published in the edition of March 23, 1980, the Brazilian Minister of Foreign Relations, Ambassador Ramiro Elysio Saraiva Guerreiro, laid open, with frankness and clearness, the fundaments of what can be called an evolution of the Brazilian Sea politics, opposite the present sequence of events and the new facts of the problem. Admitting that Brazil is not intransigent any more regarding the limitation of the Territorial Sea to 200 miles and accepting mixed formulas such as 12 miles of Sea specifically Territorial and 188 miles of an Exclusive Economic Zone, Mister Guerreiro let it be known that the Brazilian worries are not fixed in the dogmatism of a rule that practice showed was not fundamental (the 200 miles sea) but are directed to the formulas defined for the exploration of the international marine floors - the really important topic of the Conference of the Sea, already in its ninth session (mainly in the demand that exploration of those floors be fiscalized and of transference of specific technology for the said exploration).

After pointing out that Brazil is co-sponsor of a resolution in which it was established that it would not be recognized any exploration before a universal regime was defined, the Minister resumed thus, textually, the evolution of the Brazilian position, in the context of the general problem: "When the process began, there was a group of 10 or 11 countries, nine of them Latin American which had some form of unilateral legislation which extended own rights up to 200 miles, under several modalities. Brazil, Ecuador and Peru chose the classical institution of the Territorial Sea. They didn't innovate. Others had other forms of institution. These countries united in a small block because the position of the rest in the whole world was -12 miles of Territorial Sea, at the maximum. Our thesis was that there was no rule in International Law that defined Territorial Sea. The process began with this basis. During a long time, since the Prepaparatory Committee, in 1968, this group continued isolated. Little by little, our position was explained to other countries, several African countries, other Latin American, other Asian countries, were moved to find ways of protecting their resources in the adjacent sea, against the action, for example, of predatory fishing which was, then, the most visible case. That those countries assured scientific in those waters. Besides, there was the problem of the Continental Shelf because at the end of the shelf began the international area. One spoke, then, of the international area without defining the shelf. For example, we ourselves, had a national concern in the marine bottoms, that it be an arbitrary limit, that it be, for example, the average of the shelves of the world - that is 50 miles. We had, for example, a radical position, but it was possible to convince other countries in development, in the course of our conversations. Then, a current which was majority formed itself, whose goal was to reach 200 miles to project that which was of priority to the countries in development: 
the economic resources, of the sea of the marine bottoms, and of the shelves when they went beyond the 200 miles, general proposals arose from Africans and Latin-Americans, which ended up in a group called the EXCLUSIVE ECONOMIC ZONE, a term introduced by the Africans. This turned out to be the main subject of the negotiations and obviously any hypothesis of consensus should converge towards this solution. What was our interest? To evaluate what that concept of ECONOMIC ZONE offered as means of protection to Brasilian interests, which had caused, a few years before, the unilateral adoption of the Territorial Sea. In the concept itself, any examination of one's conscience shows the main interests of Brazil were protected."

That interview of Minister Saraiva Guerreiro which soon turned into the basic document of the new Brazilian sea politics, had its logical evolution in the declarations given by the Minister of the Navy, Admiral Maximiano Fonseca to the 'Correio Braziliense', of the Brazilian capital, on July 5th, 1980, in which he insists on the national position of unbendable defense of the economic resources of the sea in the 200 miles strip, superposing, thus, the merely territorial aspect (either political or of security reasons), reducible to 12 miles. The admiral then referred to an 'ambitious project' of the Brazilian Navy, called 'Cabo Frio', for the exploration of the resources of the sea' 30 .

\section{The Third Conference of the United Nations and the Law of the Sea}

The 3rd Conference of the United Nations about the law of the sea called together by Resolution 2574-A, had, in its Preparatory Committee, created by Resolution 2340 (XXII) of December 18, 1967, an articulatory organism of great importance and this one was, mainly, a political committee.

During the preparatory works from 1968 to 1973 many projects were presented, studied, and altered. The presence and work of the Latin-American representatives in the Committee was of great relevance.

The Conference in New York, in 1973 opened without a text or project agreed upon among the present States. On June 20, 1974, in Caracas, the works were morose and disheartening. Several years went by and only lately through the OFFICIAL INTEGRATED TEXT FOR NEGOTIATION (T. I. O. N.), INFORMAL COMPOSITE NEGOTIATION TEXTREVIEW 2 (ICNT), a project of a treaty was discussed.

About those problems, it is worth it to point out, that while the Committee prepared the Conference, the Latin-Americans continued to meet and present suggestions about the socalled "law of the regional sea", basing themselves on the presupposition that the existence of regional laws does not impair the existence of universal laws and, thus, formulas for a general solution could be found.

Regionalism does not express rupture in international law; on the contrary it is the expression of the multiple. For René-Jean Dupuy there are four tensions in the law of the sea, thus resumed: "De droit unidimensionel, le droit de la mer devient un droit pluridimensionel; De droit de mouvement, il devient aussi un droit d'emprise; De droit personnel, il devient aussi un droit territorial; De droit universel, il devient aussi un droit régional"31.

\footnotetext{
29 See COSTA, Vitoria dos Santos, op. cit. pp. 250-251.

30 See "Jornal do Brasil-Especial"- 3,23.3.80, "O Brasiljã não é intransigente na questão do Mar Territorial" (Brazil is not intransigent any more regarding the Territorial Sea matter), interview by Minister Saraiva Guerreiro. See "Jornal Correio Brasiliense", July, 5, 1980. Interview by Admiral Maximiano Fonseca, Brazilian Minister of Navy.

31 See DUPUY, René-Jean, Cours de Droit International Public, D.E.S., de Droit Public, Nice, 1971.
} 


\section{INFORMAL COMPOSITE NEGOTIATION TEXT (ICNT)}

The basic material for ${ }^{32}$ the present discussions is the INFORMAL COMPOSITE NEGOTIATION TEXT 2nd REVIEW that presents itself objectively as a draft Convention of the United Nations treaty on the Law of the Sea. Years of negotiations were necessary for the elaboration of the said draft even though it is still subject revisions. ICNT owns a very broad thematic and the authors tried to establish it as a project of the general treaty, objective and analytical of all the aspects which make up the Law of the Sea, or using a clear expression to jurist Jorge Vargas, the "law of the oceanic space".

In the long text, two topics are of greatest interest for Brazil: the width of the territorial sea and the width of the EXCLUSIVE ECONOMIC ZONE:

Section 2. Limites de la Mer Territoriale

Article 3

Largeur de la mer territoriale

“Tout Etat a le droit de fixer la largeur de la mer territoriale jusqu'à une limite ne dépassant pas 12 milles marins, mesurée à partir des lignes de base déterminées conformément à la Convention".

\section{Article 57}

Largeur de la Zone Economique Exclusive

"La zone économique exclusive ne s'étend pas au-delà de 200 milles marins des lignes de base à partir desquelles est mesurée la largeur de la mer territoriale".

The exploration of the marine floors, under fiscalization, to which Minister Saraiva, Guerreiro referred in his interview is assured in Section 5 of the ICNT.

As for the transference of technology from more advanced countries to countries in development, it is also foreseen in the text of the ICNT, Setion I, General Dispositions, art. 266. This Authority will present institutionalization in the exploration of the marine floors and will be concerned mainly with the situation of the States of the Third World, in relation to the transfer of marine technology (art. 274).

Faced with such perspectives, it is easy to foresee the possibility of a consensus among the States attending the Conference, mainly when it is known that the general tendency of the position concentrates in these objectives. 